\title{
Seasonal variation of the surface water quality of two dams in Plateau State, north central Nigeria
}

\author{
J. J. Gongden \& Y. N. Lohdip \\ Department of Chemistry, University of Jos, Nigeria
}

\begin{abstract}
Surface water is very vulnerable to pollution due to its ease of accessibility to human and animals, runoff from farmlands and other anthropogenic contaminations. It is one thing to have water within one's reach, and another to have it potable for use. This paper reports the seasonal variation and implication of the quality status of two surface dams located in some water-stressed communities of Plateau State, North Central Nigeria. Water quality assessments were carried out for a period of six seasons (August 2009-April 2012) using standard analytical methods. Seasonal variation of the water quality showed increasing and decreasing metal ion concentration in the dry and wet seasons, respectively, except for copper, which had a reverse trend. Seasonal values showed that most of the metals had values above their respective WHO standards for drinking water. For average concentrations, Mabudi dam had higher values of lead $(0.53 \pm 0.02) \mathrm{mg} / \mathrm{l}$, arsenic $(0.08 \pm 0.001) \mathrm{mg} / \mathrm{l}$, cobalt $(0.11 \pm 0.001) \mathrm{mg} / \mathrm{l}$ and nickel $(0.36 \pm 0.02) \mathrm{mg} / \mathrm{l}$ in the dry season than Wubang dam. Wubang dam recorded higher cadmium $(0.80 \pm 0.001) \mathrm{mg} / \mathrm{l}$ and aluminium $(1.79 \pm 0.001) \mathrm{mg} / \mathrm{l}$ values with no mercury detected throughout the period of study. Other physicochemical parameters also vary between the seasons with most of the values (for turbidity, colour, suspended and total dissolved solids) exceeding their maximum tolerable limits for both seasons. The water in both seasons had high microbial loads, with the dry season being higher. Biochemical tests on the isolates showed the presence of Staphylococcus aureus, Escherichia coli, Proteus spp. Bacillus spp. Salmonella spp. Enterobacterea, Pseudomonas spp. and Shigella, most of whose counts were higher during the dry season. Being the only sources of water for both domestic and agricultural uses in these communities, there is an urgent need for government and non-governmental organizations to address the water situation in the
\end{abstract}


communities in order to curtail the outbreak of water-related diseases, which has already affected some families based on the kind of cases being attended to within the period by the Primary Health Care Clinic in one community. Our research group is embarking on cost-effective purification methods towards alleviating the situation, as well as rain water harvesting initiatives.

Keywords: physicochemical, microbiological variations, surface water.

\section{Introduction}

The quality of every water body is of utmost importance to the beneficiary. In developing countries, as much as $80 \%$ of illnesses are linked to poor water and sanitation conditions (United Nations [1]), with nearly 1 out of every 5 deaths under the age of 5 worldwide linked to water-related disease [2]. Today, water related diseases like hepatitis are becoming resistant to most of the drugs [3]. Diarrhoea, cholera, typhoid, hepatitis and dysentery kill faster than HIV/AIDS and a whole community can be infected within a week of drinking water that contains the pathogens. The United Nations estimates that Sub-Saharan Africa alone loses 40 billion hours per year collecting water; that's the same as a whole year's worth of labour by the entire workforce in France [4]. Africa's water problem is not that of scarcity alone but pollution and inadequacy or lack of treatment of the little available water to a community. In most African communities, the major sources of water are streams, rivers, surface dams, wells, borehole and rain. In particular, most dams have become 'dams of death' due to the complexity of toxic substances and disease causing organisms they contain. Therefore heavy metals toxicity and bioaccumulation tendencies are major threats to human life and the environment.

Nagani/Wubang and Mabudi are communities in Southern Plateau State in North Central Nigeria, which face numerous water related challenges such as water shortages, pollution and floods. While the quantity of available water remain finite during the dry season, forcing the people to struggle with the cloudy sediments which are unfit for domestic purposes, the challenges are compounded by floods which wash domestic, animal and agricultural wastes into these surface dams during the rainy season. Of course the result is the outbreak of several water borne diseases (as gathered from a Primary Health Care Clinic in one of the communities). Unfortunately for these communities, there is the problem of intersecting unsaturated aquifers such that even when wells are dug, they easily caved in due to depth problems [5].

Investigations have revealed that unquantifiable amount of energy and time is lost every day in searching for portable water in the nearest town which is about $15 \mathrm{~km}$ away from the communities [6]. Children education suffers most as they are engaged in searching for water every morning instead of going to school. The outcry of the people has not attracted the attention of neither the local, state and federal government nor any non-governmental agency. Necessary steps are needed in order to save the lives of the people especially children (who are the leaders of tomorrow) in these communities from the ravaging water borne diseases.

Considering the importance of portable water, it is necessary to monitor the quality of any available water source within a community no matter how finite 
the quantity is. The physicochemical and bacteriological water parameters of Nagani/ Wubang and Mabudi dams need routine assessment since these dams remain the only sources of water in the communities with the demand increasing at geometrical rates. Knowledge of the potential pollutants in these dams can help in the control and also form the basis for the choice of any treatment method to be employed.

\section{Materials and methods}

\subsection{Water sampling and preservation}

The water samples were obtained during the peak of dry season (April) and wet season (August) from each of the dams and analysed for three consecutive years. Sampling points were selected based on ease of access and in such a way that the samples represent the entire dams.

For physicochemical parameters, the sample containers $(2 \mathrm{~L}$ plastic containers with double cap devices) were washed properly with detergent, leached with $1 \mathrm{M}$ nitric acid, rinsed with distilled water severally and finally with the water samples before collection. At each sampling point, the container was lowered completely into the water until it was filled. Samples were immediately placed in light proof insulated containers (coolers) containing melting ice with water to ensure rapid cooling and transported to the laboratory for analysis. All samples were analysed within 48 hours of sampling.

Samples for metal analysis were collected separately. To prevent loss of metals in the samples during transportation and storage, high density polyethylene containers with screw caps were used [7]. The containers (2L plastic containers with double cap devices) were leached with dilute $\mathrm{HNO}_{3}$ for several days prior to use. Thereafter, they were washed with $20 \%$ nitric acid followed by vigorous rinsing with distilled-deionised water prior to use for sample collection. At the sampling points, the container was lowered completely into the water until it was filled (2L). All the samples for metal analysis were acidified with concentrated nitric acid to $\mathrm{pH}$ of about 1.0 to 2.0 after collection before transporting to the laboratory for analysis.

For microbial analysis, sterilized and oven-dried screw capped bottles were used at each sampling point. The bottles were sterilized to avoid contamination by any physical, chemical or microbial means. Samples were analysed within one week of sampling.

\subsection{Sample analysis}

Standard analytical methods for water quality analysis recommended by the government of India and the Netherlands [8-10], were used for both physicochemical and microbial analyses. 


\section{Results and discussion}

The physicochemical characteristics of the two dam waters assessed are shown in Tables 1 and 2. The Total Viable Count of the organisms within 24 and 48 hrs of incubation $(\mathrm{cfu} / 100 \mathrm{ml})$ are presented in Tables 3 and 4 respectively.

The results of the study showed significant differences in the wet and dry seasons' values for each of the dam analysed. Colour, turbidity, suspended solids (SS), total dissolved solids (TDS) and free $\mathrm{CO}_{2}$ are generally high during the dry seasons compared to those of wet seasons. The high values could be due to the volume of water available, which is a function of pollutant concentration. Although not accumulating, hardness, oils and grease, biochemical oxygen demand (BOD), dissolved oxygen (DO), chemical oxygen demand (COD) and other parameters show regular variations between the seasons. The high values in the dry season could be attributed to the reduced volume of water in the dams with demand, increasing at geometrical rates, forcing the people and domestic animals to struggle with the cloudy sediments which are unfit for domestic purposes (see Fig. 1).

Table 1: Seasonal physicochemical characteristics of Nagani/Wubang dam water.

\begin{tabular}{|c|c|c|c|c|c|c|c|c|c|}
\hline Parameters & $\begin{array}{l}2009 \\
\text { W }\end{array}$ & $\begin{array}{l}2010 \\
\text { D }\end{array}$ & $\begin{array}{l}2010 \\
\text { W }\end{array}$ & $\begin{array}{l}2011 \\
\text { D }\end{array}$ & $\begin{array}{l}2011 \\
\text { W }\end{array}$ & $\begin{array}{l}2012 \\
\text { D }\end{array}$ & $\begin{array}{l}\text { Mean } \\
\text { W }\end{array}$ & $\begin{array}{l}\text { Mean } \\
\text { D }\end{array}$ & $\begin{array}{l}\text { WHOS } \\
\text { TD } \\
\mathbf{2 0 0 8}\end{array}$ \\
\hline Temperature ${ }^{\circ} \mathrm{C}$ & 23.80 & 22.20 & 23.30 & 27.00 & 22.30 & 27.80 & $23.13 \pm 0.76$ & $25.67 \pm 3.03$ & 30.00 \\
\hline Odour & ODL & ODL & ODL & ODL & ODL & ODL & ODL & ODL & ODL \\
\hline pH & 6.49 & 7.90 & 6.40 & 5.96 & 6.78 & 7.63 & $6.56 \pm 0.50$ & $7.16 \pm 1.18$ & $6.5-8.5$ \\
\hline Cond. $(\mu \mathrm{s} / \mathrm{cm})$ & 0.012 & 0.019 & 0.012 & 0.017 & 0.007 & 0.015 & $0.010 \pm 0.02$ & $0.017 \pm 0.02$ & 1.00 \\
\hline Total alka.(mg/l) & 72.00 & 124.0 & 40.00 & 47.00 & 60.00 & 65.00 & $57.33 \pm 16.16$ & $78.67 \pm 40.28$ & 100 \\
\hline Total $\mathrm{Cl}_{2}(\mathrm{mg} / \mathrm{l})$ & 18.00 & 0.50 & 20.00 & 36.00 & 0.03 & ND & $12.68 \pm 25.10$ & $12.19 \pm 11.00$ & 250 \\
\hline Ammonia(mg/l) & 3.30 & 15.00 & 9.90 & 16.28 & 10.32 & 11.00 & $7.84 \pm 3.94$ & $4.09 \pm 2.75$ & NS \\
\hline Fluoride(mg/l) & ND & ND & ND & ND & 0.002 & 0.002 & $0.002 \pm 0.00$ & $0.002 \pm 0.00$ & 1.50 \\
\hline Nitrate(mg/l) & 0.03 & 5.00 & 14.00 & 13.00 & 0.094 & 0.08 & $4.71 \pm 8.05$ & $6.03 \pm 6.52$ & 50.00 \\
\hline Sulphate (mg/l) & 22.00 & 25.30 & 21.00 & 22.20 & 15.00 & 24.00 & $19.33 \pm 3.79$ & $23.83 \pm 1.56$ & 500 \\
\hline Phosphate (mg/l) & 2.18 & 0.70 & 11.20 & 0.01 & 43.00 & 0.50 & $18.79 \pm 21.44$ & $0.40 \pm 0.36$ & 5.00 \\
\hline Free $\mathrm{CO}_{2}(\mathrm{mg} / \mathrm{l})$ & 0.012 & 15.00 & 10.35 & 37.00 & 6.00 & 9.00 & $5.45 \pm 5.19$ & $20.33 \pm 14.74$ & NS \\
\hline $\mathrm{DO}(\mathrm{mg} / \mathrm{l})$ & 20.40 & 21.00 & 20.20 & 13.70 & 8.10 & 46.00 & $16.23 \pm 10.54$ & $26.90 \pm 6.83$ & 5.00 \\
\hline $\mathrm{HC}_{\mathrm{S}}(\mathrm{mg} / \mathrm{l})$ & ND & 0.01 & ND & 0.10 & ND & 1.25 & ND & $0.45 \pm 0.05$ & 0.007 \\
\hline Phenols(mg/l) & ND & ND & ND & ND & 0.11 & ND & $0.11 \pm 0.00$ & ND & 1.00 \\
\hline $\mathrm{H}_{2} \mathrm{~S}(\mathrm{mg} / \mathrm{l})$ & 0.02 & ND & ND & 1.82 & ND & ND & $0.02 \pm 0.00$ & $1.82 \pm 0.00$ & NS \\
\hline Pesticides(mg/l) & 0.003 & ND & ND & ND & ND & ND & $0.003 \pm 0.00$ & ND & 0.01 \\
\hline Mercury & ND & ND & ND & ND & ND & ND & ND & ND & 0.01 \\
\hline Manganese & 0.003 & 0.02 & ND & 0.03 & 0.10 & 0.02 & $0.051 \pm 0.07$ & $0.02 \pm 0.01$ & 0.50 \\
\hline Nickel & ND & 0.02 & ND & ND & ND & ND & ND & $0.02 \pm 0.00$ & 0.02 \\
\hline Cobalt & 0.02 & ND & ND & 0.03 & 0.04 & 0.08 & $0.03 \pm 0.01$ & $0.04 \pm 0.04$ & NS \\
\hline Chromium & ND & ND & ND & 0.07 & 0.027 & ND & $0.03 \pm 0.00$ & $0.07 \pm 0.00$ & 0.05 \\
\hline
\end{tabular}

Key: $\mathrm{D}=$ Dry season; $\mathrm{W}=$ Wet season; $\mathrm{ODL}=$ Odourless; $\mathrm{ND}=$ Not detected; $\mathrm{NS}=\mathrm{Not}$ stated; $\mathrm{STD}=$ Standard. 
Table 2: Seasonal physicochemical characteristic of Mabudi dam water.

\begin{tabular}{|c|c|c|c|c|c|c|c|c|c|}
\hline Parameters & $\begin{array}{l}2009 \\
\text { W }\end{array}$ & $\begin{array}{l}2010 \\
\text { D }\end{array}$ & $\begin{array}{l}2010 \\
W\end{array}$ & $\begin{array}{l}2011 \\
\text { D }\end{array}$ & $\begin{array}{l}2011 \\
\text { W }\end{array}$ & $\begin{array}{l}2012 \\
\text { D }\end{array}$ & $\begin{array}{l}\text { Mean } \\
\text { W }\end{array}$ & $\begin{array}{l}\text { Mean } \\
\text { D }\end{array}$ & $\begin{array}{l}\text { WHO } \\
\text { STD } \\
2008\end{array}$ \\
\hline Temperature ${ }^{\circ} \mathrm{C}$ & 24.10 & 21.80 & 24.50 & 28.30 & 22.50 & 29.40 & $23.70 \pm 1.06$ & $26.50 \pm 4.11$ & 30.00 \\
\hline Odour & ODL & ODL & ODL & ODL & ODL & ODL & ODL & ODL & ODL \\
\hline pH & 6.43 & 7.23 & 6.51 & 8.26 & 6.88 & 7.70 & $6.62 \pm 0.24$ & $7.73 \pm 0.52$ & $6.5-8.5$ \\
\hline Turbidity (NTU) & 15.00 & 98.00 & 40.00 & 133.0 & 7.00 & 373.0 & $20.67 \pm 17.21$ & $201.3 \pm 149.7$ & 5.00 \\
\hline Cond. $(\mu \mathrm{s} / \mathrm{cm})$ & 0.011 & 0.036 & 0.012 & 0.038 & 0.019 & 0.014 & $0.014 \pm 0.004$ & $0.029 \pm 0.013$ & 1.00 \\
\hline Total alka.(mg/l) & 120.0 & 33.00 & 12.00 & 18.31 & 29.00 & 105.0 & $53.67 \pm 58.07$ & $52.10 \pm 46.39$ & 100 \\
\hline Total $\mathrm{Cl}_{2}(\mathrm{mg} / \mathrm{l})$ & 10.40 & 19.51 & 11.20 & 0.15 & 0.01 & 0.06 & $7.20 \pm 6.24$ & $6.57 \pm 11.20$ & 250 \\
\hline Ammonia(mg/l) & 3.70 & 23.91 & 10.00 & 20.39 & 0.85 & 20.18 & $14.55 \pm 4.68$ & $21.49 \pm 2.10$ & NS \\
\hline Fluoride(mg/l) & 0.012 & 0.25 & 0.05 & 2.00 & 2.10 & 0.001 & $0.72 \pm 1.19$ & $0.75 \pm 1.09$ & 1.50 \\
\hline Nitrate(mg/l) & 10.10 & 3.80 & 5.10 & 0.001 & 0.076 & 0.077 & $5.09 \pm 5.01$ & $1.29 \pm 2.17$ & 50.00 \\
\hline Sulphate (mg/l) & 40.00 & 44.00 & 33.00 & 56.70 & 13.00 & 75.00 & $28.67 \pm 14.01$ & $58.57 \pm 15.58$ & 500 \\
\hline Phosphate (mg/l) & 12.01 & 0.70 & 3.90 & 0.01 & 0.33 & 0.034 & $5.41 \pm 5.99$ & $0.24 \pm 0.39$ & 5.00 \\
\hline Free $\mathrm{CO}_{2}(\mathrm{mg} / \mathrm{l})$ & 6.21 & 14.00 & 4.88 & 15.00 & 8.00 & 6.00 & $6.36 \pm 1.57$ & $11.67 \pm 4.93$ & NS \\
\hline $\mathrm{DO}(\mathrm{mg} / \mathrm{l})$ & 12.30 & 13.38 & 18.90 & 10.50 & 7.70 & 6.20 & $12.97 \pm 5.63$ & $10.02 \pm 3.61$ & 5.00 \\
\hline $\mathrm{HC}_{\mathrm{S}}(\mathrm{mg} / \mathrm{l})$ & 1.16 & 0.23 & 0.02 & 1.20 & 0.05 & 2.80 & $0.41 \pm 0.65$ & $1.41 \pm 1.30$ & 0.007 \\
\hline Phenols(mg/l) & 0.001 & 0.19 & 0.001 & 0.032 & 0.003 & 2.50 & $0.002 \pm 0.00$ & $0.91 \pm 1.38$ & 1.00 \\
\hline $\mathrm{H}_{2} \mathrm{~S}(\mathrm{mg} / \mathrm{l})$ & 0.04 & 3.20 & 0.01 & 2.10 & ND & ND & $0.03 \pm 0.02$ & $2.65 \pm 0.78$ & NS \\
\hline Pesticides(mg/l) & 0.002 & ND & 0.004 & 0.01 & ND & ND & $0.003 \pm 0.01$ & $0.01 \pm 0.00$ & 0.01 \\
\hline Mercury & ND & 0.001 & ND & 0.02 & ND & 0.01 & ND & $0.01 \pm 0.01$ & 0.01 \\
\hline Manganese & ND & ND & ND & 0.11 & 0.10 & 0.21 & $0.10 \pm 0.00$ & $0.16 \pm 0.07$ & 0.50 \\
\hline Nickel & ND & 0.01 & ND & 0.93 & 0.03 & 0.15 & $0.03 \pm 0.00$ & $0.36 \pm 0.50$ & 0.02 \\
\hline Copper & 2.00 & 0.16 & 2.30 & 2.92 & 3.20 & 0.32 & $2.50 \pm 0.62$ & $1.03 \pm 0.55$ & 2.00 \\
\hline Cobalt & ND & 0.21 & 0.01 & 0.11 & 0.001 & 0.003 & $0.01 \pm 0.01$ & $0.11 \pm 0.10$ & NS \\
\hline Chromium & 0.02 & 0.03 & 0.005 & 0.07 & 0.02 & 0.21 & $0.02 \pm 0.01$ & $0.10 \pm 0.09$ & 0.05 \\
\hline Cadmium & 2.00 & 1.91 & ND & 0.14 & ND & 0.04 & $2.00 \pm 0.00$ & $0.70 \pm 1.05$ & 0.05 \\
\hline Aluminium & 1.30 & 2.61 & 2.30 & 3.50 & 0.01 & 0.03 & $1.20 \pm 1.15$ & $1.71 \pm 1.80$ & 0.20 \\
\hline Calcium & 42.10 & 16.00 & 42.11 & 40.00 & 22.00 & 23.00 & $35.40 \pm 11.01$ & $26.33 \pm 12.34$ & 100 \\
\hline Magnesium & 15.40 & 17.00 & 85.30 & 18.00 & 18.00 & 19.00 & $39.57 \pm 39.63$ & $14.66 \pm 1.00$ & 20.00 \\
\hline
\end{tabular}

Key: $\mathrm{D}=$ Dry season; $\mathrm{W}=$ Wet season; ODL=Odourless; $\mathrm{ND}=$ Not detected; $\mathrm{NS}=$ Not stated; $\mathrm{STD}=$ Standard.

Table 3: Total Viable Count (TVC) of the water samples cultured within 24 hours incubation (cfu/100ml).

\begin{tabular}{lllll}
\hline Sample & PCA & MCA & EMB & SSA \\
\hline Nagani/Wubang & $4.96 \times 10^{2}$ & $3.76 \times 10^{2}$ & $2.88 \times 10^{2}$ & $2.16 \times 10^{2}$ \\
& $\left(2.86 \times 10^{2}\right)$ & $\left(1.63 \times 10^{2}\right)$ & $\left(1.40 \times 10^{2}\right)$ & $\left(1.32 \times 10^{2}\right)$ \\
Mabudi & $2.56 \times 10^{2}$ & $2.96 \times 10^{2}$ & $1.20 \times 10^{2}$ & $7.60 \times 10^{2}$ \\
& $\left(1.33 \times 10^{2}\right)$ & $\left(1.11 \times 10^{2}\right)$ & $\left(1.10 \times 10^{2}\right)$ & $\left(3.97 \times 10^{2}\right)$ \\
\hline
\end{tabular}

$(\ldots)=$ Wet season values.

Key: PCA=Plate Count Agar; MCA=Mackonkay Agar; EMB=Eosin Methylene Blue; SSA=Salmonella Shigella Agar. 
Table 4: TVC of the water samples cultured within 48 hours incubation (cfu/100ml).

\begin{tabular}{lllll}
\hline Sample & PCA & MCA & EMB & SSA \\
\hline Nagani/ & $5.60 \times 10^{2}$ & $6.40 \times 10^{2}$ & $5.68 \times 10^{2}$ & $3.84 \times 10^{2}$ \\
Wubang & $\left(2.29 \times 10^{2}\right)$ & $\left(3.61 \times 10^{2}\right)$ & $\left(2.31 \times 10^{2}\right)$ & $\left(1.24 \times 10^{2}\right)$ \\
Mabudi & $4.72 \times 10^{2}$ & $5.68 \times 10^{2}$ & $2.16 \times 10^{2}$ & $1.44 \times 10^{2}$ \\
& $\left(2.18 \times 10^{2}\right)$ & $\left(2.44 \times 10^{2}\right)$ & $\left(1.64 \times 10^{2}\right)$ & $\left(1.07 \times 10^{2}\right)$ \\
\hline
\end{tabular}

$(\ldots)=$ Wet season values.

Key: PCA=Plate Count Agar; MCA=Mackonkay Agar; EMB=Eosin Methylene Blue; $\mathrm{SSA}=$ Salmonella Shigella Agar.

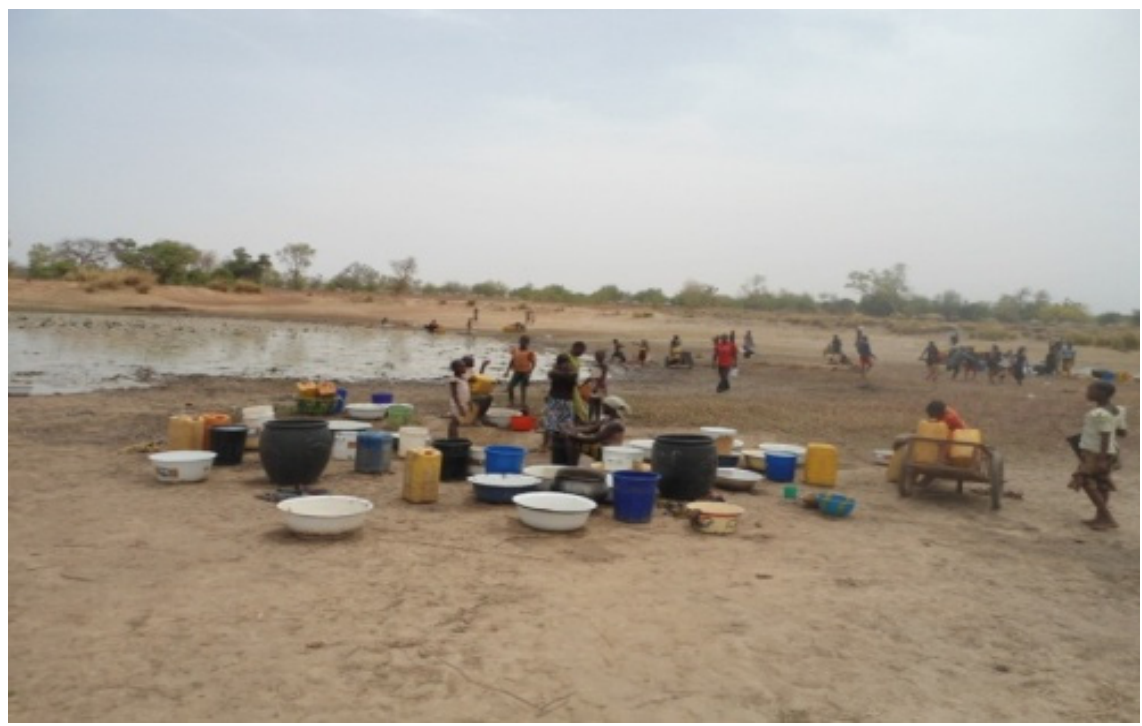

Figure 1: Water scarcity situation in Nagani/Wubang dam during the dry season.

Majority of the concentration of metals in the dams are significant and justifiable by the value of the total dissolved solids obtained. Seasonal variation shows increase in metal ion concentration in the dry season and correspondent decrease in the wet season for the three year study, with the exception of copper which shows an inverse relation. This situation is expected in view of the reduction in the pollution in the wet season arising from increased dilution and water flow. Water volume reduces during the dry season, making the dissolved metals to be at higher concentration levels in the liquid phase. Zinc, copper and cobalt vary significantly in Nagani/Wubang while arsenic, zinc, lead, iron, copper and cobalt show positive correlation between the seasons in Mabudi dam. In Nagani/Wubang dam, there was no mercury detected in the water. Apart from aluminium, lead and cadmium, most metallic concentrations are low for both seasons. Cadmium concentration is $0.80 \pm 0.001 \mathrm{mg} / 1$ and $0.71 \pm 0.00 \mathrm{mg} / 1$ for dry and wet seasons respectively. Lead has mean seasonal concentrations of $0.28 \pm 0.00 \mathrm{mg} / \mathrm{l}$ and 
$0.12 \pm 0.00) \mathrm{mg} / \mathrm{l}$ for dry and wet seasons. This is also higher than the WHO (2008) standard of $0.01 \mathrm{mg} / \mathrm{l}$. Aluminium concentration is very high $(1.79 \pm 0.001$, $0.84 \pm 0.00) \mathrm{mg} / \mathrm{l}$, far above the WHO limit of $0.20 \mathrm{mg} / 1$ [3]. The high value cannot be unconnected with the washing of aluminium pots (which most of the households use) and utensils around the dam especially during the dry season when there is acute shortage of water.

Mabudi dam also has high concentration of metal ions. Seasonal mean concentration shows the following values for dry and wet seasons; Arsenic $(0.08 \pm 0.00,0.007) \mathrm{mg} / \mathrm{l}$, zinc $(1.47 \pm 0.02,1.47 \pm 0.01) \mathrm{mg} / \mathrm{l}$, lead $(0.53 \pm 0.00$, $0.005 \pm 0.00) \mathrm{mg} / 1, \quad \operatorname{copper}(1.03 \pm 0.51, \quad 2.50 \pm 0.02) \mathrm{mg} / 1, \quad$ cobalt $\quad(0.11 \pm 0.00$, $0.01 \pm 0.00) \mathrm{mg} / \mathrm{l}$, chromium $(0.10 \pm 0.00,0.02 \pm 0.00) \mathrm{mg} / \mathrm{l}$, cadmium $(0.70 \pm 0.00$, $2.00 \pm 0.00)$, nickel $(0.36 \pm 0.00,0.03 \pm 0.00) \mathrm{mg} / \mathrm{l}$. Closeness of the dam to traffic, washing of vehicles and other domestic cleanings may be responsible for the high concentrations of these metals in Mabudi dam.

Even though quite a number of metals, such as manganese (Mn), zinc ( $\mathrm{Zn})$, and copper $(\mathrm{Cu})$ are essential for biochemical processes that sustain life, these same metals, and a variety of others, can be severely toxic to aquatic organisms in high concentrations. The metals can be toxic to humans as well, if they are ingested directly in water, or if they accumulate in organisms that are higher in the food chain and are consumed by humans [7, 11]. The level of pollution of these dams in terms of their metal ion concentrations calls for a serious attention in order to avoid the deadly effects that may result from continuous consumption of these waters on the long run.

Although both dams had some level of faecal contamination, Nagani/Wubang had higher microbial loads of $4.96 \times 10^{2}$ and $2.86 \times 10^{2} \mathrm{cfu} / 100 \mathrm{ml}$ on plate count agar (PCA) after 24 hours of incubation in both dry and wet seasons respectively. Identified bacteria based on biochemical tests on the isolates included Staphylococcus aureus, Escherichia coli, Proteus spp. Bacillus spp. Salmonella spp. Enterobacterea, Pseudomonas spp. and Shigella, most of which are higher during the dry season.

\section{Conclusion}

The physicochemical parameters of the dam waters analysed showed that all the dams are contaminated with heavy metals, bacteria and other non-essential ions in varied degrees and gave cause for alarm. Inadequate management practices, fertilizer use, runoff from farmlands, domestic cleanings and animal grazing within the vicinities of the dams are possible routes through which these dams may have been contaminated.

Most of the values of the parameters analysed are not in conformity with WHO standard limits which make the water unsafe for drinking [12]. For instance, Staphylococcus aureus, Escherichia coli, Proteus spp. Bacillus spp. Salmonella spp. Enterobacterea, Pseudomonas spp. and Shigella were all identified in the samples with high loads recorded during the dry season. Cadmium, nickel, chromium, lead, copper, cobalt, aluminium and zinc concentrations were alarmingly high in some cases during the dry season and this can be deleterious to 
health. High turbidity, colour and suspended solids in most of the dams make them physically unpalatable. Our research group is embarking on cost effective purification ways towards alleviating the situation, as well as rain water harvesting initiatives.

\section{References}

[1] United Nations (2003). Statement by Secretary General Koffi Annan. http://www.un.org/News/Press/docs/2003/sgsm8707.doc.htm. Retrieved 1st January, 2009.

[2] World Health Organisation, WHO/UNICEF (2009). 'Diarrhoea: Why children are still dying and what can be done.' http://www.unicef.org/health/index_51412.html. Retrieved 15th March, 2010.

[3] Solt, K. Nagy, T. Esohan, A. Csandy, M. and Hollos, T. (1994). An Outbreak of Hepatitis 'A' due to a Thermal Spa. Budapesti Kozegeszsegugy. 26(1): 8-12.

[4] United Nations Development Programme, UNDP (2009). 'Resource Guide on Gender and Climate Change.'

http://www.undp.org/climatechange/library_gender.shtml. Retrieved 11th June, 2010.

[5] Lohdip, Y. N. and Gongden, J. J. (2009) Climate change and dams drying: A case study of three communities in Mabudi, Langtang South of Plateau State, Nigeria. African Journal of Natural Sciences, 12, 37-43 (2009).

[6] Lohdip, Y. N. (2011). 'The Insolvency of the Universal Solvent: That All May Have Enough to Drink'. 52 ${ }^{\text {nd }}$ Inaugural Lecture of the University of Jos, delivered on Friday $29^{\text {th }}$ July, 2011, 41-49.

[7] Environmental Protection Agency, EPA (2001). Parameters of Water Quality. Interpretation and Standards. Johnstown Castle co. Wexford, Ireland, 82.

[8] Hydrology Project (1999). Standard Analytical Procedure. Government of India and Government of the Netherlands. Laboratory Technical Assistance Manual. 19th edition, New Delhi, India, 1-45, 50-82.

[9] Hydrology Project (2003). Technical Assistance Manual. Government of India \& Government of the Netherlands. Laboratory Technical Assistance Manual. Final Report (June 2003), 130.

[10] Patil. P. N, Sawant. D. V, Deshmukh. R. N. (2012). Physico-chemical parameters for testing of water - A review: International Journal of Environmental Sciences 3(3), 1195-1207.

[11] World Health Organization (2005). Sources and Containers. Background document for preparation of WHO Guidelines for Drinking-water Quality. Geneva, World Health Organization (WHO/HSE/AMR/08.03/9). Retrieved 10th March, 2013.

[12] World Health Organization, WHO (2008). Guidelines for Drinking Water Quality: Supporting Documentation to Guidelines. 3rd edition. 2, 552. 